\title{
Patterns of inheritance of the symptoms of Huntington's disease suggestive of an effect of genomic imprinting
}

\author{
R M Ridley, C D Frith, L A Farrer, P M Conneally
}

\begin{abstract}
The interaction of symptomatology (rigidity/chorea) in Huntington's disease (HD) with age of onset (AO) was examined using data from the Research Roster for Huntington's Disease Patients and Families. It was shown that AO varies between families and between paternal and maternal transmission and that rigidity is associated specifically with very early onset, major anticipation, paternal transmission, and young parental AO. It is proposed that AO depends on the state of methylation of the HD locus, which varies as a familial trait, and as a consequence of 'genomic imprinting' determined by parental transmission. Young familial AO and paternal imprinting interact to produce, occasionally, a major change in gene expression, that is, the early onset/rigid variant.
\end{abstract}

Genomic imprinting is the process by which genes are labelled as being of paternal or maternal origin. The

Division of Psychiatry, Clinical Research Centre, Northwick Park Hospital, Watford Road, Harrow, Middlesex HAI 3UJ.

R M Ridley, C D Frith

Department of Neurology and School of Public Health, Boston University School of Medicine, and Department of Neurology, Harvard University Medical School, 80 East Concord Street, Boston, MA 02118, USA.

L A Farrer

Department of Medical Genetics, Indiana University School of Medicine, Indiana, Indianapolis, USA.

P M Conneally

Correspondence to Dr Ridley.

Received for publication 25 September 1990.

Accepted for publication 28 September 1990. mechanism of genomic imprinting involves the degree of methylation of chromosomal segments. ${ }^{12}$ Changes in the degree of methylation of DNA can also control gene activation and inactivation and can occur as part of the ageing process. ${ }^{3}$ It has been suggested that differences in genomic methylation may be responsible for the differences in age of onset $(\mathrm{AO})$ which are observed in cases of Huntington's disease (HD) depending on whether the HD allele is inherited from the mother or the father, ${ }^{45}$ and it is possible that differences in genomic imprinting may also underlie differences in symptomatology. The later $\mathrm{AO}$ of $\mathrm{HD}$ in the offspring of affected mothers compared to offspring of affected fathers has been attributed to a maternal protective factor ${ }^{6-8}$ and, although it has been suggested that this factor could be found in maternal mitochondrial DNA, ${ }^{6}$ it could equally well exist in maternal genomic imprinting.

We have previously reported that maternal inheritance does not result in a change in mean $\mathrm{AO}$ across generations but that cases of paternal inheritance fall into two distinct groups, the larger showing a decrease in $\mathrm{AO}$ of $\sim 4$ years and the smaller group $(\sim 6 \%)$ showing a decrease of $\sim 24$ years. ${ }^{4} \mathrm{~A}$ decrease in $\mathrm{AO}$ from one generation to the next has been called anticipation. It is usually thought to result from ascertainment bias, for example, people with very young AO do not become parents or parents with a young AO may die shortly after the birth of their children such that data are not remembered or are lost because of family breakdown (see reference 4 for further discussion). The data base used here produced very little anticipation in the maternal line suggesting that general ascertainment bias cannot explain the anticipation observed in the paternal line. Some ascertainment bias could be affected by sex, for example, data may be more frequently lost about fathers than mothers because of illegitimacy or family 
breakdown. Since prodromal behaviour may directly contribute to these events, data on young onset fathers may be differentially lost. The analysis in this paper shows, however, that young onset fathers make a special contribution to the distribution of $\mathrm{AO}$ in offspring. This would not arise from an ascertainment bias in which young onset fathers were not reported.

In this paper we examine the extent to which parental (and grandparental) inheritance affects symptomatology in HD. We do this by considering cases which present with or without muscular rigidity. Although rigidity is known to be associated with paternal inheritance -11 and early $\mathrm{AO},{ }^{912} 13$ we show here that rigidity is also associated with major anticipation and young paternal AO. This deviation from normal regression (where the offspring of young onset parents would show negative anticipation) indicates that a change in genomic expression has occurred in these rigid cases. This change may involve the degree of methylation of the HD allele.

\section{Methods}

Data on symptoms were acquired by questionnaire from members of the Research Roster for Huntington's Disease Patients and Families. ${ }^{9}$ Questionnaire data that were ascertained from living, first degree relatives were supplemented by medical and genealogical records kept by the roster. Chorea was defined as "starting as involuntary tics or jerk-like spasms and intensifying during disease progression until voluntary movements including facial expression could no longer be controlled". Rigidity was defined as "almost the opposite of chorea, appearing as generalized muscle stiffness and slight tremors in one or more parts of the body". AO was defined as the first time any signs or symptoms appeared which were either neurological or psychiatric and which represented a permanent change from the normal state.

Group means were compared using ANOVA with equal weights applied to the cells, followed by the Newman-Keuls multiple range test (package P7D from the BMDP statistical software ${ }^{14}$ ). The ability of the covariates to predict membership of subgroups (for example, rigid $v$ choreic) was examined using stepwise logistic regression (package PLR from the BMDP statistical software ${ }^{14}$ ). This method selects predictor variables in a stepwise fashion. The dependent variable is binary, while the independent variables can be categorical or continuous. The predicted proportion of the two subgroups composing the dependent variable follows the logistic model $\exp (U) /(1+\exp (U))$ where $U$ is a linear function of the independent variables. ${ }^{15}$ At each step in the stepping process one independent variable is added to or removed from the model. The step selections are based on the maximum likelihood ratio. The procedure will also handle interactions between independent variables. A hierarchical rule was applied so that interactions were only allowed into the model if lower order interactions and main effects were already in the model.

\section{Results}

\section{PARENTAL ORIGIN OF RIGID CASES}

Table 1 shows that rigid cases tended to have an affected father rather than an affected mother (Fisher's test, $p<0.02$ ). In agreement with previous observations, ${ }^{46716}$ paternal origin produced a younger AO overall (34 (SE 0.69)) than maternal origin (39 (SE 0.64), p<0.001). There was, however, a significant interaction between symptomatology and parental origin $(F(1,58)=6.8, p<0.01)$. Rigid cases of paternal origin had a much earlier $A O$ than any other group (Newman-Keuls test, $\mathrm{p}<0.01$ ) suggesting that some special event may have occurred to produce these unusual cases. The effect of paternal origin was, however, not confined to this group since, for choreic cases, paternal origin still produced an earlier $\mathrm{AO}$ than maternal origin (Tukey test, $\mathrm{p}<0.01$ ).

Overall the offspring of affected fathers showed significant anticipation, that is, the tendency to have an earlier $\mathrm{AO}$ than their affected parent $(6.6$ years, $p<0.001$ ) while the offspring of affected mothers did not. The rigid offspring of affected fathers showed substantial anticipation (15 years, $\mathrm{p}<0.001)$. In this respect they differed significantly from the other three groups (Neuman-Kuels, p<0.05). This occurred despite the fact that, as a group, rigid cases had fathers with a younger $\mathrm{AO}$ than fathers or mothers of choreic cases (Newman-Keuls test, $p<0 \cdot 05$ ). (If anticipation simply reflected regression to the mean then the offspring of young onset fathers would show negative anticipation.)

Table 1 Symptomatology, age of onset, and parental age of onset.

\begin{tabular}{|c|c|c|c|c|c|c|c|c|}
\hline & \multicolumn{4}{|c|}{ Paternal origin } & \multicolumn{4}{|c|}{ Maternal origin } \\
\hline & Choreic & No & Rigid & No & Choreic & No & Rigid & No \\
\hline \multirow{2}{*}{$\begin{array}{l}\text { AO proband } \\
\text { AO parent } \\
\text { Anticipation in } \\
\text { proband }\end{array}$} & $\begin{array}{l}36(0 \cdot 64)^{*} \\
41(0.83)\end{array}$ & $\begin{array}{l}236 \\
141\end{array}$ & $\begin{array}{l}18(2.4) \\
33(1.9)\end{array}$ & $\begin{array}{l}20 \\
19\end{array}$ & $\begin{array}{l}40(0.64) \\
39(0.85)\end{array}$ & $\begin{array}{l}258 \\
146\end{array}$ & $\begin{array}{l}32(4 \cdot 5) \\
39(7 \cdot 6)\end{array}$ & $\begin{array}{l}8 \\
5\end{array}$ \\
\hline & $5.6(0.9)$ & 141 & $15(2 \cdot 2)$ & 19 & $0.6(0.7)$ & 146 & $2 \cdot 4(4 \cdot 3)$ & 5 \\
\hline
\end{tabular}

*Years (SEM). 
Table 2 Relationship of symptomatology and age of onset to grandparental origin.

\begin{tabular}{|c|c|c|c|c|c|c|c|c|}
\hline & $\mathbf{G F} \rightarrow \mathbf{F}$ & No & $\mathbf{G M} \rightarrow \mathbf{F}$ & No & $\mathbf{G F} \rightarrow \mathbf{M}$ & No & $\mathbf{G M} \rightarrow \mathbf{M}$ & No \\
\hline $\begin{array}{l}\text { Choreic } \\
\text { AO proband } \\
\text { AO parent } \\
\text { AO grandparent } \\
\text { Anticipation in proband } \\
\text { Anticipation in parent }\end{array}$ & $\begin{array}{l}34(1 \cdot 1)^{*} \\
40(1 \cdot 0) \\
44(2 \cdot 3) \\
6 \cdot 1(1 \cdot 3) \\
2 \cdot 3(2 \cdot 0)\end{array}$ & $\begin{array}{l}54 \\
54 \\
15 \\
54 \\
15\end{array}$ & $\begin{array}{l}34(1 \cdot 5) \\
40(1 \cdot 3) \\
44(3 \cdot 2) \\
5 \cdot 1(1 \cdot 3) \\
4 \cdot 7(2 \cdot 5)\end{array}$ & $\begin{array}{l}55 \\
55 \\
14 \\
55 \\
14\end{array}$ & $\begin{array}{l}38(1 \cdot 6) \\
37(1 \cdot 3) \\
43(2 \cdot 5) \\
-1 \cdot 6(1 \cdot 3) \\
7 \cdot 9(2 \cdot 7)\end{array}$ & $\begin{array}{l}51 \\
51 \\
14 \\
51 \\
14\end{array}$ & $\begin{array}{l}37(1 \cdot 4) \\
38(1 \cdot 6) \\
37(2 \cdot 3) \\
1 \cdot 1(1 \cdot 1) \\
2 \cdot 3(2 \cdot 8)\end{array}$ & $\begin{array}{l}52 \\
52 \\
15 \\
52 \\
15\end{array}$ \\
\hline $\begin{array}{l}\text { Rigid } \\
\text { AO proband } \\
\text { AO parent } \\
\text { AO grandparent } \\
\text { Anticipation in proband } \\
\text { Anticipation in parent }\end{array}$ & $\begin{array}{l}14(2 \cdot 7) \\
33(2 \cdot 8) \\
45(2 \cdot 4) \\
19(1 \cdot 6) \\
17(2 \cdot 3)\end{array}$ & $\begin{array}{l}9 \\
9 \\
3 \\
9 \\
3\end{array}$ & $\begin{array}{l}18(2 \cdot 8) \\
31(2 \cdot 8) \\
30(4 \cdot 1) \\
13(3 \cdot 9) \\
0 \cdot 8(3 \cdot 5)\end{array}$ & $\begin{array}{l}8 \\
8 \\
4 \\
8 \\
4\end{array}$ & $\begin{array}{l}40(12) \\
46(11) \\
52 \\
6(6 \cdot 4) \\
-4 \cdot 0\end{array}$ & $\begin{array}{l}3 \\
3 \\
1 \\
3 \\
1\end{array}$ & $\begin{array}{l}31(1 \cdot 4) \\
28(4 \cdot 0) \\
-3(3 \cdot 0) \\
-\end{array}$ & $\begin{array}{l}2 \\
2 \\
0 \\
2 \\
0\end{array}$ \\
\hline
\end{tabular}

*Years (SEM). GF grandfather, GM grandmother, $F$ father, $M$ mother.

These results show that rigid symptomatology is associated with at least four variables: early onset, anticipation, paternal origin, and early onset in the affected parent. A further way of examining those parents likely to produce very early onset, rigid cases is to look at the grandparental origin of rigid cases.

EFFECTS OF GRANDPARENTAL ORIGIN

Table 2 shows the usual effect of paternal transmission on $\mathrm{AO}$ in both generations especially for the rigid probands. There were only eight rigid cases for whom the $\mathrm{AO}$ in the affected parent and affected grandparent were both known. In the three cases inherited from the father and grandfather, substantial anticipation occurred in both generations. This did not occur in any other lineage. Nevertheless, in this small data set, there was no detectable effect of grandparental origin on probability of occurrence of a rigid case.

PREDICTION OF JUVENILE CASES

Juvenile onset HD has often been the subject of special attention ${ }^{10} 1^{17-21}$ and these cases have also been put forward as a special subgroup of HD. We examined the variables that predict the juvenile form of the disease (defined as an AO at 20 years or less). Table 3 shows the parental and grandparental origin of juvenile and adult onset cases. In agreement with previous analyses, juvenile cases are more likely to be rigid $^{910}$ and of paternal origin. ${ }^{10} 19$ In addition, table 3 shows that juvenile cases show large anticipation and tend to have early onset parents and grandparents.

That juvenile cases tend to show anticipation is to be expected, firstly because a group selected on the basis of very young $\mathrm{AO}$ is going to be of younger onset than its parents who were not selected for young onset and, secondly, because selection for parenthood excludes cases where young AO precluded marriage and reproduction. Nevertheless, since AO is highly correlated within families, ${ }^{1623-25} 37$ the parents of juvenile cases are likely to have a younger AO than average. The dual influence of young familial $\mathrm{AO}$ and the paternal anticipation effect can be seen in table 3 . In the GM-M line both mother and grandmother have a young $\mathrm{AO}$ indicating an overall young familial AO. In the GF-M line the mother also has a young AO but the grandfather need not be of young onset

Table 3 Grandparental origin of juvenile and adult cases.

\begin{tabular}{|c|c|c|c|c|c|c|c|c|}
\hline & $\mathbf{G F} \rightarrow \mathbf{F}$ & No & $\mathbf{G M} \rightarrow \mathbf{F}$ & No & $\mathbf{G F} \rightarrow \mathbf{M}$ & No & $\mathbf{G M} \rightarrow \mathbf{M}$ & No \\
\hline $\begin{array}{l}\text { Adult } \\
\text { AO proband } \\
\text { AO parent } \\
\text { AO grandparent } \\
\text { Anticipation in proband } \\
\text { Anticipation in parent } \\
\text { Rigidity }\end{array}$ & $\begin{array}{l}36(0.64)^{*} \\
41(0.62) \\
43(1 \cdot 2) \\
4 \cdot 8(0 \cdot 67) \\
2 \cdot 3(1 \cdot 2) \\
2 / 52(4 \%)\end{array}$ & $\begin{array}{r}208 \\
208 \\
60 \\
208 \\
60\end{array}$ & $\begin{array}{c}38(0.63) \\
43(0.64) \\
43(1 \cdot 2) \\
5 \cdot 1(0 \cdot 59) \\
-0.89(1 \cdot 0) \\
3 / 50(6 \%)\end{array}$ & $\begin{array}{r}234 \\
234 \\
75 \\
234 \\
75\end{array}$ & $\begin{array}{l}38(0.56) \\
38(0.57) \\
42(1 \cdot 2) \\
0.32(0 \cdot 45) \\
5 \cdot 5(1 \cdot 0) \\
2 / 49(4 \%)\end{array}$ & $\begin{array}{r}293 \\
293 \\
71 \\
293 \\
71\end{array}$ & $\begin{array}{l}39(0.55) \\
40(0.55) \\
40(1 \cdot 1) \\
1.3(0.43) \\
0.16(81) \\
2 / 53(4 \%)\end{array}$ & $\begin{array}{r}301 \\
301 \\
96 \\
301 \\
96\end{array}$ \\
\hline $\begin{array}{l}\text { Fuvenile (<20 years) } \\
\text { AO proband } \\
\text { AO parent } \\
\text { AO grandparent } \\
\text { Anticipation in proband } \\
\text { Anticipation in parent } \\
\text { Rigidity }\end{array}$ & $\begin{array}{l}13(0 \cdot 73) \\
31(1 \cdot 1) \\
38(1 \cdot 3) \\
18(1 \cdot 1) \\
8 \cdot 2(1 \cdot 5) \\
7 / 11(64 \%)\end{array}$ & $\begin{array}{l}66 \\
66 \\
31 \\
66 \\
31\end{array}$ & $\begin{array}{l}15(0 \cdot 88) \\
29(1 \cdot 1) \\
34(1 \cdot 9) \\
15(1 \cdot 3) \\
3 \cdot 3(1 \cdot 9) \\
5 / 13(38 \%)\end{array}$ & $\begin{array}{l}37 \\
37 \\
23 \\
37 \\
23\end{array}$ & $\begin{array}{l}17(1 \cdot 1) \\
25(1 \cdot 9) \\
38(2 \cdot 7) \\
8 \cdot 5(2 \cdot 5) \\
11 \cdot 8(3 \cdot 7) \\
1 / 5(20 \%)\end{array}$ & $\begin{array}{l}21 \\
21 \\
13 \\
21 \\
13\end{array}$ & $\begin{array}{l}17(1 \cdot 1) \\
27(1 \cdot 5) \\
28(2 \cdot 5) \\
9 \cdot 9(1 \cdot 9) \\
1 \cdot 6(4 \cdot 6) \\
0 / 2(0 \%)\end{array}$ & $\begin{array}{r}19 \\
19 \\
7 \\
19 \\
7\end{array}$ \\
\hline
\end{tabular}

*Years (SEM). 
Table 4 Grandparental origin of normal and major anticipation.

\begin{tabular}{|c|c|c|c|c|c|c|c|c|}
\hline & $\mathbf{G F} \rightarrow \mathbf{F}$ & No & $\mathbf{G M} \rightarrow \mathbf{F}$ & No & $\mathrm{GF} \rightarrow \mathbf{M}$ & No & $\mathbf{G M} \rightarrow \mathbf{M}$ & No \\
\hline $\begin{array}{l}\text { Normal anticipation } \\
\text { AO proband } \\
\text { AO parent } \\
\text { AO grandparent } \\
\text { Anticipation in proband } \\
\text { Anticipation in parent } \\
\text { Rigidity }\end{array}$ & $\begin{array}{l}34(0.79)^{*} \\
37(0.62) \\
41(1.3) \\
2.9(0.56) \\
6.0(1 \cdot 1) \\
1 / 47(2 \%)\end{array}$ & $\begin{array}{r}198 \\
198 \\
60 \\
198 \\
60\end{array}$ & $\begin{array}{l}37(0 \cdot 76) \\
40(0.69) \\
41(1 \cdot 2) \\
3.4(0.47) \\
0.49(0.98) \\
5 / 51(6 \%)\end{array}$ & $\begin{array}{r}225 \\
225 \\
79 \\
225 \\
79\end{array}$ & $\begin{array}{l}37(0.61) \\
37(0.57) \\
41(1 \cdot 1) \\
-0 \cdot 21(0.40) \\
6 \cdot 9(1 \cdot 1) \\
2 / 52(4 \%)\end{array}$ & $\begin{array}{r}296 \\
296 \\
78 \\
296 \\
78\end{array}$ & $\begin{array}{l}38(0.61) \\
38(0.60) \\
39(1 \cdot 1) \\
0.55(0.37) \\
1.0(0.69) \\
2 / 51(4 \%)\end{array}$ & $\begin{array}{r}298 \\
298 \\
95 \\
298 \\
95\end{array}$ \\
\hline $\begin{array}{l}\text { Major anticipation } \\
\text { (>15 years) } \\
\text { AO proband } \\
\text { AO parent } \\
\text { AO grandparent } \\
\text { Anticipation in proband } \\
\text { Anticipation in parent } \\
\text { Rigidity }\end{array}$ & $\begin{array}{l}20(1 \cdot 0) \\
42(1 \cdot 3) \\
43(1 \cdot 3) \\
22(0 \cdot 71) \\
1 \cdot 0(1 \cdot 9) \\
8 / 16(50 \%)\end{array}$ & $\begin{array}{l}76 \\
76 \\
31 \\
76 \\
31\end{array}$ & $\begin{array}{l}25(1 \cdot 7) \\
46(1 \cdot 6) \\
38(2 \cdot 4) \\
21(8 \cdot 3) \\
-1 \cdot 5(2 \cdot 6) \\
3 / 12(25 \%)\end{array}$ & $\begin{array}{l}46 \\
46 \\
19 \\
46 \\
19\end{array}$ & $\begin{array}{l}28(3 \cdot 0) \\
46(2 \cdot 7) \\
41(5 \cdot 0) \\
18(1 \cdot 9) \\
-0 \cdot 3(3 \cdot 5) \\
1 / 2(50 \%)\end{array}$ & $\begin{array}{r}18 \\
18 \\
6 \\
18 \\
6\end{array}$ & $\begin{array}{c}33(2 \cdot 5) \\
51(2 \cdot 3) \\
39(4 \cdot 4) \\
19(0 \cdot 91) \\
-9 \cdot 1(5 \cdot 8) \\
0 / 3(0 \%)\end{array}$ & $\begin{array}{r}22 \\
22 \\
8 \\
22 \\
8\end{array}$ \\
\hline
\end{tabular}

*Years (SEM).

because of anticipation in his offspring. Affected fathers tend to have a little older $\mathrm{AO}$ than affected mothers and affected grandfathers have a slightly older AO than affected grandmothers because they produce anticipation in their offspring.

\section{PREDICTION OF MAJOR ANTICIPATION}

In our previous study ${ }^{4}$ we suggested that cases showing major anticipation might form a special subgroup of HD. We therefore investigated whether the subgroup defined by major anticipation was similar to that defined by rigidity in terms of the variables that predict group membership. Major anticipation was defined as occurring when the $\mathrm{AO}$ of the proband was $>15$ years less than the affected parent.

Table 4 shows the grandparental origin of cases with normal and major anticipation. Major anticipation is associated with rigidity, early onset, and paternal origin. These cases, however, tend to have parents with a later onset than the parents of rigid cases. Anticipation is by definition large in probands in this group, but it is noticeable that there is no anticipation in the parents and indeed anticipation is strongly negative in mothers of major anticipation in the GM-M line. Thus, in the GM-M line, major anticipation represents a fluctuation about a family mean.

Comparing tables 2, 3, and 4 it is noteworthy that selection by rigidity produces an $\mathrm{AO}$ in the offspring of affected fathers which is as young as that produced by selection by juvenile onset or major anticipation, even though juvenile onset and anticipation select for young $\mathrm{AO}$ for mathematical reasons, whereas selection for rigidity does not. Selection by rigidity also produces as much anticipation in the offspring of fathers as does selection by juvenile onset or selection by anticipation, even though these latter two necessarily produce anticipation in the proband.
Anticipation in the parent is interesting in that a marked (grand)paternal effect is evident in cases selected for juvenile onset but not in cases selected for anticipation. This is because anticipation in the proband may be the result of normal regression to the mean following negative anticipation in the parent, whereas juvenile onset may require the combination of anticipation and young parental AO which, itself, may have been acquired by anticipation from a grandfather. Unfortunately, there are few rigid cases for which anticipation in the parent is known, but it is striking that in the three cases of grandpaternal origin there is major anticipation in the parent whereas in the four cases of grandmaternal origin there is not. Overall, these three analyses show patterns in $\mathrm{AO}$ and anticipation which can be predicted from the selection process inherent in looking at juvenile and major anticipation cases in combination with the known paternal effect. Selection by rigidity, however, produces marked effects on $\mathrm{AO}$ and anticipation which indicate a complex interaction between this symptom, parental origin, $\mathrm{AO}$, and anticipation.

\section{VARIANCE ACROSS FAMILIES}

A number of studies ${ }^{16}{ }^{23-25} 37$ have shown that $\mathrm{AO}$ of HD is more homogeneous within than across families. We confirmed this effect by contrasting the variance in AO within sibships in the same family and the variance in AO across these sibships. There were 729 sibships with at least two affected sibs (average of 2.6 sibs per family). Sibships with affected fathers were analysed separately from those with affected mothers, since we might expect to see a greater variation in AO in sibships with affected fathers. There were 345 sibships with affected fathers and 384 sibships with affected mothers. For both data sets the variance between sibships was significantly greater than that within sibships although, contrary to expectation, 
Table 5 Variance in $A O$ in $H D$.

\begin{tabular}{lrrrc}
\hline Source of variance & df & MS & $\begin{array}{c}\text { ratio } \\
\text { Families of affected fathers }\end{array}$ & p \\
$\begin{array}{l}\text { Between families } \\
\text { Within families }\end{array}$ & $\begin{array}{rrrr}344 \\
546\end{array}$ & $\begin{array}{r}277.0 \\
55.0\end{array}$ & 5.04 & $<0.0001$ \\
$\begin{array}{l}\text { Families of affected mothers } \\
\begin{array}{l}\text { Between families } \\
\text { Within families }\end{array}\end{array}$ & $\begin{array}{rrrr}383 \\
243.8\end{array}$ & 6.57 & $<0.0001$ \\
\hline
\end{tabular}

there was no significant difference between the sibships with affected fathers and those with affected mothers (table 5).

\section{ASSOCIATION BETWEEN RIGIDITY, AO, AND PARENTAL ORIGIN}

In this paper we have discussed three possible variant forms of HD: the rigid form, the juvenile form, and the anticipating form. All these forms are associated with one another and also with an affected father and young parental AO. We wanted to consider, however, whether any of these forms of $\mathrm{HD}$ reflect the operation of some single basic process. An attempt was made to answer this question using stepwise regression to predict the occurrence of a particular form of HD on the basis of the other variables we have considered. In this procedure the association with the dependent variables is estimated. A predictive model is then constructed on the basis of the single variable that is most highly associated. Partial associations are then calculated to see if any of the remaining variables can be added to the model to increase its predictive power. The procedure is repeated until no further improvement in predictive power (indicated by increase in log likelihood) is achieved. If more than one step is required for the model, this implies that at least two independent processes underlie the occurrence of this form of HD. We looked at the relationships between five variables: type of movement disorder (rigid or choreic), sex of affected parent, AO, AO of affected parent, and anticipation in onset. However, one of the last three variables is redundant, since anticipation is completely determined by $\mathrm{AO}$ and $\mathrm{AO}$ of affected parent. In table $6 \mathrm{~A}$, models using $\mathrm{AO}$ and $\mathrm{AO}$ of affected parent are examined, while in table 6B models using anticipation are examined. In each model a particular form of HD (for example, rigid $v$ choreic) was predicted from the other three variables. In each case the same 311 subjects were used, for whom data on all four variables were available.

\section{Fuvenile cases (age of onset $\leqslant 20$ )}

There were 35 juvenile and 276 non-juvenile cases. The model best predicting juvenility was very complex (table 6). The best predictor was rigidity. However, when this variable was removed associations still remained with $\mathrm{AO}$ of parent, sex of parent, and their interaction. This reflects the fact that there are offspring of affected fathers who have juvenile onset, but are not rigid. In addition, there is another type of juvenile case who are the offspring of affected mothers who, themselves, had a very early $\mathrm{AO}$. These results suggest that a number of processes underlie the occurrence of juvenile cases.

Cases of anticipation (age of onset $\geqslant 15$ years earlier than that of affected parent)

There were 37 anticipating cases and 264 normal cases. The best model had two factors corresponding to single variables: rigidity and sex of affected parent (table 6). Anticipating cases were more likely to be rigid. In addition, the offspring of affected fathers were more likely to be anticipators.

Table 6 Predicting form of $H D$.

(A) Variables: age of onset, parent's age of onset, sex of affected parent, and motor status

\begin{tabular}{llc}
\hline $\begin{array}{l}\text { Dependent } \\
\text { variable }\end{array}$ & Solution & -2 log likelihood \\
\hline $\begin{array}{l}\text { Onset status } \\
\text { Motor status }\end{array}$ & $\begin{array}{l}\mathrm{j}=1 \cdot 04 \mathrm{r}-0 \cdot 20 \text { pao+1.97psex }-0 \cdot 10 \text { (pao }{ }^{*} \text { psex) }+4.69 \\
\mathrm{r}=0.13 \mathrm{ao}-1 \cdot 38\end{array}$ & 146 \\
\hline
\end{tabular}

(B) Variables: anticipation, sex of affected parent, motor status

\begin{tabular}{llc}
\hline $\begin{array}{l}\text { Dependent } \\
\text { variable }\end{array}$ & Solution & -2 log likelihood \\
\hline $\begin{array}{l}\text { Anticipation } \\
\text { status }\end{array}$ & $\begin{array}{l}\mathrm{a}=-0.83 \mathrm{r}+0.70 \mathrm{psex}+1.61 \\
\text { Motor status }\end{array} \mathrm{r}=-0.09 \mathrm{ant}+3 \cdot 16$ & 200 \\
\hline
\end{tabular}

J=onset status: $1=$ juvenile ( $\leqslant 20$ years), $2=$ adult onset.

$\mathrm{r}=$ motor status: $1=$ choreic, $2=$ rigid.

$a=$ anticipation status: $1=$ small, $2=$ large ( $>15$ years).

$\mathbf{a o}=$ age of onset (years), $\mathbf{p a o}=$ parent's age of onset (years), ant $=$ anticipation (pao-ao), psex $=$ sex of affected parent: $1=$ father, $2=$ mother. 
These results also suggest two processes are at work determining anticipation. Some anticipators are early onset cases with rigidity, but also (and this is consistent with the results discussed above) the offspring of fathers are more likely to be anticipators even when they are choreic.

\section{Rigid cases}

There were 24 rigid cases and 287 choreic cases. The two models for rigidity needed only one factor. AO of proband or anticipation were sufficient to predict rigidity (table 6). The cases predicted in this way also had affected fathers, anticipated, and had early onset parents. These results suggest that only one process underlies the appearance of rigidity. There was little difference between the models in goodness of fit, but in both cases the simple model predicting rigidity had the better fit.

Thus, on the basis of simplicity, the most likely interpretation of these data is that cases with rigidity are a distinct form of Huntington's disease. Although these cases are also likely to have juvenile onset and large anticipation, cases of juvenile onset and anticipation can also occur in the absence of rigidity. These probably reflect other processes. In particular, juvenile onset can occur by normal variation in a family which has a characteristically early AO.

\section{Discussion}

This statistical analysis of AO in HD has shown: (1) that $A O$ varies significantly less within than across families; (2) that paternal transmission significantly decreases AO by $\sim 5$ years in choreic probands; (3) that paternal transmission is also significantly associated with the occurrence of a distinct clinical variant of HD characterised by rigidity, very early onset, and major anticipation ( $>15$ years); and (4) that the affected fathers of early onset/rigid cases have a significantly earlier AO than other affected parents. This can result either from major anticipation from their father (the proband's grandfather) or from an overall young $A O$ in their family. In either case the major anticipation in their rigid offspring is all the more surprising since normal regression would produce negative anticipation in the offspring of young onset parents. Our previous analysis ${ }^{4}$ showed that anticipation in offspring actually became greater as the fathers' AO decreased, particularly when the disease was inherited from the grandmother. This suggests an interaction between the magnitude of the paternal transmission effect and the family specific AO.

In addition to occurring as part of the rigid variant, juvenile onset can occur when the parent's $A O$ is also very young and major anticipation can occur when the parent's AO is very old, both as a result of normal variation. These two features in isolation do not therefore define a clinical variant. In this respect we agree with van Dijk et $a l^{10}$ that juvenile rigid HD is a clinical variant with special features but that juvenile HD per se is not. Stevens ${ }^{26}$ also concluded that rigid HD was the only true variant of HD in that it had unusual features in addition to the defining symptoms. Rigidity was occasionally reported in our sample independently of early onset, major anticipation, or paternal transmission. This reported rigidity may sometimes occur only as a terminal symptom or as a consequence of diagnostic uncertainty, although one family has been reported with several rigid cases inherited through the mother. ${ }^{27}$

Our proposition is that AO depends on the state of methylation of the HD locus and that the degree of methylation is heritable in a moderately variable manner, resulting in characteristic mean AOs in different families and lineages. It is known that the parental origin of genes alters the degree of methylation by a process known as 'genomic imprinting' and we propose that paternal imprinting accounts for the $\sim 5$ year decrease in AO in choreic cases acquired from the father. Furthermore, paternal imprinting seems to interact with the methylation state determining the familial AO producing, occasionally, a major change in gene expression, that is, the early onset/rigid variant. The younger the $\mathrm{AO}$ in the father the greater the probability of the occurrence of this catastrophic interaction. This is shown by the young AO of the fathers of rigid cases, by the greater sensitivity of some families to the paternal transmission effect on $\mathrm{AO},,^{28}$ and by the excess occurrence of rigid cases among the sibs of rigid probands. Ten rigid probands in this sample had three rigid compared with 12 non-rigid sibs, that is, $25 \%$ of sibs where $\sim 5 \%$ is predicted by chance. Bittenbender and Quadfase ${ }^{17}$ reported that 46/70 rigid cases came from families with at least one other rigid or akinetic case. This familial clustering may occur if paternal imprinting and young familial AO both involve relative demethylation and the combination of the two sometimes falls below some critical level. Too few rigid subjects in this study became parents for an assessment of the heritability of rigidity to be made, but Brackenridge ${ }^{11}$ reported a considerable excess of rigid fathers among the affected parents of rigid cases. Bittenbender and Quadfase ${ }^{17}$ described five pedigrees in which nine rigid, or very atypical, young onset cases had three rigid fathers and one rigid mother but only one choreic father. This suggests that the major epigenetic change leading to rigidity is heritable.

It is possible that the onset of symptoms is actually caused by an age related demethylation resulting in pathological levels of gene expression at the HD locus. This may account for the relationship between early onset and more severe and rapid disease progression. ${ }^{18}$ It is also possible that the primary 
defect in the HD allele consists of a peculiarity in the methylation state rather than a mutation in the amino acid sequence, but there is no evidence about this at present. In this respect, however, it is of interest that HD homozygotes do not exhibit earlier AO or more rapid disease progression than heterozygotes ${ }^{30} 31$ as might be expected if their symptoms were the result of phenotypic amplification of an abnormal gene product expressed throughout life.

Although the methylation state of the HD locus is not known because the HD locus itself cannot be finally identified it is likely that the HD locus is subject to variable methylation since Pritchard $e a^{32}$ have shown that the D4S95 locus, which is closely linked to $H D$, is subject to variable methylation.

Can the pattern of symptomatology and distribution of AO described here and previously ${ }^{4}$ be explained by other theories? The scarcity of juvenile onset or rigid cases or both in the offspring of affected women has been attributed to a maternal protective factor ${ }^{6-8}$ but this begs the question of protection from what? In this analysis, AO in the offspring of women does not differ from that predicted by normal variation and regression. It is, therefore, the decreased AO in the offspring of affected men which requires particular explanation. There may, however, be other factors, which operate only in the offspring of affected females or which operate in the offspring of either affected sex, which influence $A O$ in individual cases. The occurrence of early onset/rigid cases is not the result of genetic heterogeneity involving different loci, since families which show marked phenotypic differences show linkage to the same marker. ${ }^{28}{ }^{29}$ Nor do they arise from allelic heterogeneity at the same locus since the association of early onset rigid cases with major anticipation shows that they occur as the children of adult onset cases. Early onset cases show reduced fecundity and do not replace themselves in the population. ${ }^{633}$ Early onset/rigid cases are too frequent $(\sim 5 \%)$ to be the consequence of separate mutation events. The sibs of rigid cases showed an excess of rigid cases in this analysis and the sibs of juvenile cases also show very early onset. ${ }^{25}$ This clustering would not occur as a consequence of random mutation during gametogenesis.

Differences in AO between paternal and maternal cases cannot be explained as a general effect of paternal imprinting ${ }^{3}$ since paternal transmission produces a bimodal distribution in AO. ${ }^{4}$ Farrer $e t a^{34}$ have suggested that $\mathrm{AO}$ may be controlled by multiple 'ageing genes' within affected families. AO was found to be correlated, among other factors, with age at death of unaffected family members. Juvenile onset was found never to occur in families with an average old $\mathrm{AO}^{24}$ (and putative superior ageing genes) and, in our analysis, early onset/rigid cases occur specifically among the offspring of early onset parents. Senescence itself may, however, be controlled by methylation changes ${ }^{3}$ such that inherited superior and inferior ageing factors may be epigenetic or involve epigenetic mechanisms. Farrer et $a^{34}$ proposed an interaction between paternal transmission and ageing factors comparable to the proposition about methylation made here.

An effect of genomic imprinting on gene expression and $\mathrm{AO}$ may not be unique to $\mathrm{HD}$. A similar effect of paternal origin on AO has been observed in spinocerebellar ataxia, ${ }^{35} 36$ while maternal imprinting may result in more severe disease in some forms of myotonic dystrophy. ${ }^{22}$ Thus AO in HD may be an archetype from which epigenetic mechanisms controlling reduced penetrance and variable expression in other genetic diseases may be understood. Furthermore, since rigid cases rarely become parents because of their young $\mathrm{AO}$, the occurrence of this variant of HD may be used as a model against which to assess the genetics of other seriously deleterious conditions which persist in the population despite a clear loss of fecundity. Thus, a disease with a clear genetic component but with markedly reduced penetrance may be a severe variant of another innocuous genetic condition but the occurrence of this variant may result from epigenetic mechanisms rather than from the influence of environmental precipitants.

1 Reik W, Collick A, Norris ML, Barton SC, Surani MA. Genomic imprinting determines methylation of parental alleles in transgenic mice. Nature 1987;328:248-51.

2 Sapienza C, Peterson AC, Rossant J, Balling R. Degree of methylation of transgenes is dependent on gamete of origin. Nature 1987;328:251-4.

3 Holliday R. The significance of DNA methylation in cellular ageing. In: Woodhead $\mathrm{AD}$, Blackett $\mathrm{AD}$, Hollaender $\mathrm{A}$, eds. Molecular biology of ageing. New York: Plenum Press, 1985: 269-83.

4 Ridley RM, Frith CD, Crow TJ, Conneally PM. Anticipation in Huntington's disease is inherited through the male line but may originate in the female. $\mathcal{F}$ Med Genet 1988;25:589-95.

5 Reik W. Genomic imprinting: a possible mechanism for the parental origin effect in Huntington's chorea. $f$ Med Genet 1988;25:805-8.

6 Boehnke $M$, Conneally PM, Lange $K$. Two models for a maternal factor in the inheritance of Huntington disease. Am $\mathcal{J ~ H u m}$ Genet 1983;35:845-60.

7 Myers RH, Cupples LA, Schoenfeld M, et al. Maternal factors in onset of Huntington disease. Am J Hum Genet 1985;37:511-23.

8 Farrer LA, Conneally PM. A genetic model for age of onset in Huntington disease. Am f Hum Genet 1985;37:350-7.

9 Farrer LA, Conneally PM. Predictability of phenotype in Huntington's disease. Arch Neurol 1987;44:109-13.

10 van Dijk JG, van der Velde EA, Roos RAC, Bruyn GW. Juvenile Huntington disease. Hum Genet 1986;73:235-9.

11 Brackenridge CJ. Parental factors associated with rigidity in Huntington's disease. F Med Genet 1980;17:112-4.

12 Brackenridge CJ. A genetical statistical study of some sex related factors in Huntington's disease. Clin Genet 1971;2:287-97.

13 Brackenridge CJ. The relation of the sex of choreic and rigid subjects to the age at onset of Huntington's disease. Clin Genet 1974;5:248-53.

14 BMDP Statistical Software Manual. Los Angeles: University of California Press, 1985.

15 Cox DR. The analysis of binary data. London: Methuen, 1975.

16 Newcombe RG, Walker DA, Harper PS. Factors influencing age of onset and duration of survival in Huntington's chorea. Ann Hum Genet 1981;45:387-96.

17 Bittenbender JB, Quadfasel FA. Rigid and akinetic forms of Huntington's disease. Arch Neurol 1962;7:275-88. 
18 Merritt AD, Conneally PM, Rahman NF, Drew AL. Juvenile Huntington's chorea. Excerpta Medica Int Cong Ser 1969;175: 645-73.

19 Brackenridge CJ. The relation of sex of affected parent to the age of onset of Huntington's disease. $\mathcal{F}$ Med Genet 1973;10: 333-6.

20 Myers RH, Goldman D, Bird ED, et al. Maternal transmission in Huntington's disease. Lancet 1983;i:208-10.

21 Went LN, Vegter-van der Vlis MR, Bruyn GW. Parental transmission in Huntington's disease. Lancet 1984; i:1100-2.

22 Harper PS. Congenital myotonic dystrophy in Britain. II. Genetic basis. Arch Dis Child 1975;50:514-21.

23 Wallace DC, Hall EC. Evidence of genetic heterogeneity in Huntington's chorea. I Neurol Neurosurg Psychiatry 1972;35 789-800.

24 Went LN, Vegter-van der Vlis M, Bruyn GW, Volkers WS. Huntington's chorea in the Netherlands. Ann Hum Genet 1983;47:205-14.

25 Hayden MR, Soles JA, Ward RH. Age of onset in siblings of persons with juvenile Huntington disease. Clin Genet 1985;28: $100-5$.

26 Stevens DL. Huntington's chorea: a demographic, genetic and clinical study. MD thesis, University of London, 1976.

27 Bird MT, Paulson GW. The rigid form of Huntington's chorea. Neurology 1971;21:271-6.

28 Folstein SE, Phillips JA, Meyers DA, et al. Huntington's disease: two families with differing clinical features show linkage to the G8 probe. Science 1985;229:776-9.

29 Sax DS, Bird ED, Gusella JF, Myers RH. Phenotypic variation in 2 Huntington's disease families with linkage to chromosome 4. Neurology 1989;39:1332-6.

30 Wexler NS, Young AB, Tanzi RE, et al. Homozygotes for Huntington's disease. Nature 1987;326:194-7.

31 Myers RH, Leavitt J, Farrer LA, et al. Homozygote for Huntington disease. Am $\mathcal{F}$ Hum Genet 1989;45:615-8.

32 Pritchard CA, Cox DR, Myers RM. Methylation at the Hunting ton disease-linked D4S95 locus. Am f Hum Genet 1989;45: 335-6.

33 Jones MB. Fertility and age of onset in Huntington's chorea. In: Barbeau A, Chase TN, Paulson GW, eds. Advances in neurology. Vol 1. New York: Raven Press, 1973:171-7.

34 Farrer LA, Conneally PM, Yu PI. The natural history of Huntington disease: possible role of ageing genes. Am $\mathcal{F}$ Med Genet 1984;18:115-23.

35 Harding AE. Genetic aspects of autosomal dominant late onset cerebellar ataxia. 7 Med Genet $1981 ; 18: 436-41$.

36 Zoghbi HY, Pollack MS, Lyons LA, Ferrell RE, Daiger SP, Beaudet AL. Spinocerebellar ataxia: variable age of onset and linkage to HLA in a large kindred. Ann Neurol 1988;23:580-4.

37 Pericak-Vance MA, Elston RC, Conneally PM, Dawson DV. Age of onset heterogeneity in Huntington disease families. Am $\mathcal{F}$ Med Genet 1983;14:49-59. 